\title{
GEOSPATIAL PERSPECTIVE FOR POST-HARVEST INFRASTRUCTURE MANAGEMENT: POSITIONING OF NEW COLD STORAGE
}

\author{
Pavan Vijjapu, M. M. Kimothi*, Shreya Roy, S. Mamatha and S. S. Ray \\ Mahalanobis National Crop Forecast Centre, DAC\&FW, New Delhi - pavanvijjapu@hotmail.com, (drmmkimothi, royshreya406, \\ mamata.sanapala, shibendu.ray)@gmail.com
}

Commission III, WG 10

KEY WORDS: Bihar, Potato, Cold storages, Remote Sensing, GIS, Crop Production, Clustering techniques

\begin{abstract}
:
The deficiency in post-harvest infrastructure leads to loss of agricultural produce which in turn affects farmer's income and food security. So, there is a need to improve post-harvest infrastructure in the country. Potato is a major horticultural crop requiring cold storage facility. This study was carried out for Bihar state of India, which has the least ratio of storage capacity to potato production in comparison to other states. An approach has been developed to identify the suitable locations for cold storages using geospatial technology to increase accessibility to cold storage facilities. Temporal variations in vegetation profiles were used to generate crop maps and from this crop area proportions were calculated at village level. These proportions were used to identify significant village clusters contributing to horticulture production. From this priority villages were identified. These priority villages were assigned to nearest major settlement which will be the sites for positioning new cold storage facility. The approach developed in this study has identified 63 locations in 17 districts for developing new cold storage facility. The proposed new locations for cold storages will reduce the distance to nearest cold storage for 14244 villages and this reduction in distance will be more than 8 kms for 9774 villages. Thus, the study validated the role of Remote Sensing and GIS for post-harvest infrastructure planning.
\end{abstract}

\section{INTRODUCTION}

Over the years, horticulture has emerged as one of the potential agricultural enterprise in accelerating the growth of economy. Its role in the country's nutritional security, poverty alleviation and employment generation programmes is becoming increasingly important. It offers not only a wide range of options to the farmers for crop diversification, but also provides ample scope for sustaining large number of agro industries which generate huge employment opportunities. In order to develop a database of the existing major horticultural crops and to promote holistic growth of the Horticultural sector, Department of Agriculture, Cooperation and Farmer's Welfare of Ministry of Agriculture \& Farmers' Welfare has formulated a programme under the Mission for Integrated Development of Horticulture (MIDH) initiated the project in September 2014, called CHAMAN (Coordinated Horticulture Assessment and Management using geo-informatics), for better horticulture assessment and development through remote sensing, GIS and field data (Ray et al., 2016).

The main objectives of the programme are: a. Area assessment and production forecasting of 7 major horticultural crops in selected district of major states. b. Geospatial applications for Horticultural Development and Management Planning for i) Site Suitability, ii) Post-Harvest Infrastructure, iii) Crop Intensification, iv) GIS database creation, v) Orchard Rejuvenation, vi) Aqua-horticulture and c. Detailed scientific field level studies for developing technology for crop identification, yield modelling and disease assessment

\footnotetext{
*Corresponding Author
}

Various schemes are going on under Ministry of Agriculture \& Farmers Welfare, which are directly or indirectly related to development of Horticulture sector. The Mission for Integrated Development of Horticulture directly deals with overall development of horticulture. In this context, it is proposed to use remote sensing data along with GIS tool for integrating various information, such as land use/Land cover, cropping system and production, Infrastructure, hydro-geomorphology, ground water prospect, topography (DEM), weather, soil, socioeconomic etc. data to develop decision supports for various horticultural development plans. One or two pilot studies have been taken up under each of the 6 components identified under CHAMAN programme objective-2 for Horticulture developments planning purposes.

In this context, a pilot study was taken up to assess the potential of existing crops and available post-harvest infrastructure and to evolve optimum plan for allocating post-harvest infrastructure at district/block and village cluster level using satellite remote sensing data and Geographic Information System.

India ranks second in the world in fruit and vegetable production with a 280.4 million MT/ annum produce (DAC, 2014). Post-harvest losses range from $5.8 \%$ to $18 \%$ in case of fruits and $6.8 \%$ to $12 \%$ for vegetables (Hegazy, 2013). Hence, there is a need to understand the post-harvest infrastructure scenario in the country. Post-harvest infrastructure includes various types of facilities like cold storages, food processing industries, packaging facility, market outlets, etc. Of these cold storages are the most important in the case of fruits and vegetables as they prolong the shelf life of the produce and in maintaining the quality. As per the All India Cold Chain Infrastructure Capacity (Assessment of Status \& Gap), 2015 report by National Centre for Cold Chain Development, the total cold storage capacity requirement is 350.97 lakh tonnes and total available is 318.24 Lakh Tonnes. Hence, there is a gap 
of more than 32.76 lakh MT of cold storage capacity in the country (NCCD, 2015). Thus, there is a need to improve the cold storage infrastructure.

Potato is the major horticulture contributor which is also a significant occupier of cold storage space. Though 90 per cent cold storage facilities of the country is for potato crop and is located in the potato growing regions, still it falls far below the requirement (Ray et al., 2000). Here the state of Bihar was considered for the pilot study as it is a significant contributor to fruits and vegetables production, producing more than 16 million MT accounting $7.72 \%$ of horticultural production in the country and having very low storage capacity (Figure 1).

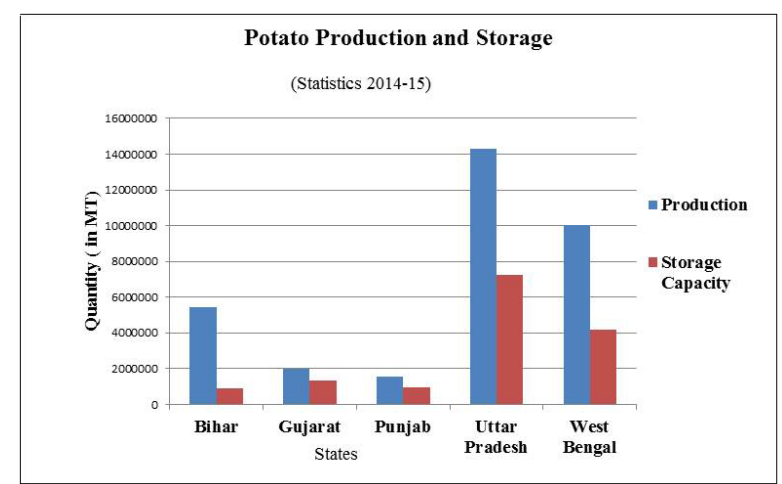

Figure 1. The production of potato crop and storage capacity for each of the major potato growing state of India

The objective of this study is to identify regions requiring cold storage infrastructure and positioning new cold storages using geospatial technology in order to increase the ease of access to cold storage infrastructure, thereby improving farmer's income by increasing the shelf life of their produce.

\section{STUDY AREA}

The state of Bihar has a geographical extent of 9. million hectares of which 1.15 million hectares is under horticulture. It is a major contributor to fruits and vegetables in the country producing more than 16 million MT accounting for $7.72 \%$ of horticultural production (DAC,2014). It has 38 districts with varying crop patterns and has three crop seasons-Kharif, Rabi and Zaid (Figure 2).

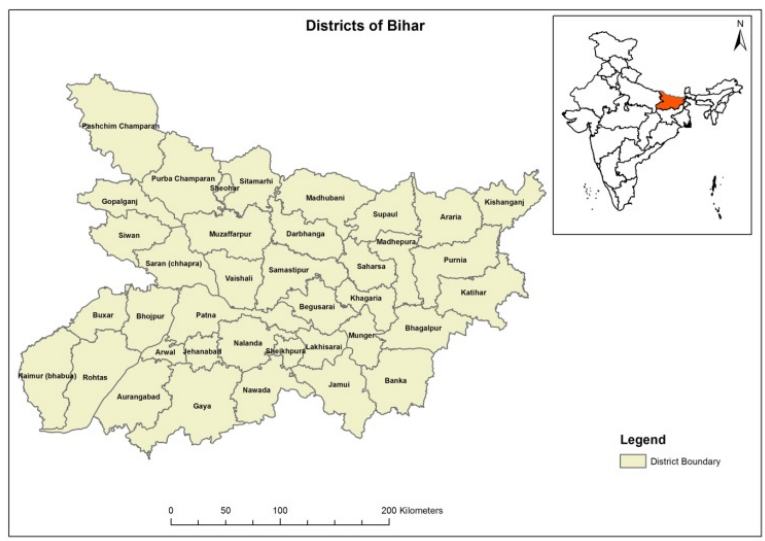

Figure 2. Pilot Study Area the state of Bihar
Area, production and productivity statistics for various fruits and vegetables produced in Bihar is shown in Figure 3. Bihar being one of the major producers of potato has least storage capacity ratio among major potato producing states (Figure 1). Hence, the state was chosen for the pilot study.

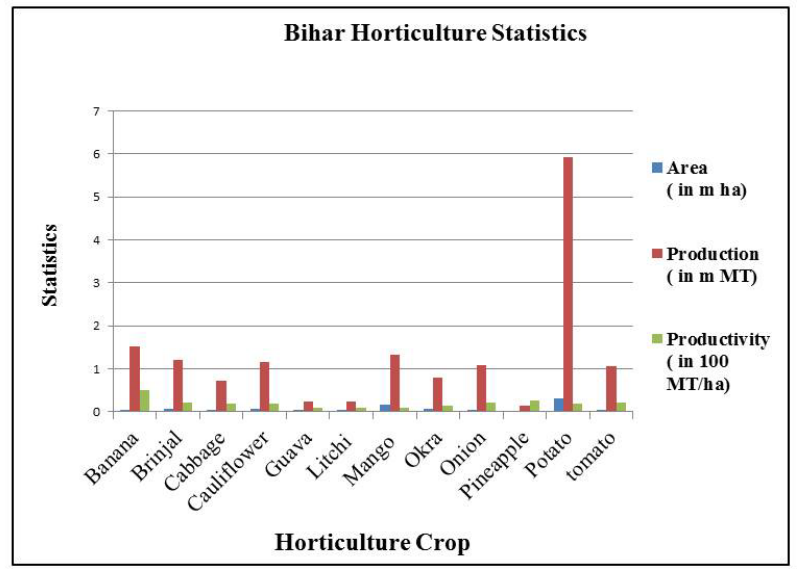

Figure 3. Major horticulture crop statistics (area, production and productivity) of Bihar State

\section{MATERIALS AND METHODS}

\subsection{Data used}

The required data as inputs are crop maps, LULC information, administrative boundaries and infrastructure. Multi-temporal satellite imagery of AWiFS (Advanced Wide Field sensor) NDVI products, LISS III and Landsat 8 were used in the creation of the potato crop map. The AWiFS NDVI product was acquired between $1^{\text {st }}$ November, 2014 and $15^{\text {th }}$ February, 2015 at an interval of 15 days. In addition to AWiFS, LISS III and Landsat- 8 data were used for reference between the said periods. Besides satellite data Land use/Land Cover map, vector layer (major road and tabular information), as mentioned in the Table 1, were used in this study.

\begin{tabular}{|l|l|l|l|}
\hline Data Type & Format & $\begin{array}{l}\text { Data } \\
\text { Source }\end{array}$ & $\begin{array}{l}\text { Time } \\
\text { Period }\end{array}$ \\
\hline $\begin{array}{l}\text { Potato Classified } \\
\text { Map }\end{array}$ & $\begin{array}{l}\text { Classified } \\
\text { Raster Map }\end{array}$ & $\begin{array}{l}\text { CHAMAN } \\
\text { Project }\end{array}$ & $\begin{array}{l}2014- \\
15\end{array}$ \\
\hline $\begin{array}{l}\text { Land Use/Land } \\
\text { Cover (LULC) } \\
1: 250 \mathrm{~K}\end{array}$ & $\begin{array}{l}\text { Classified } \\
\text { Raster Map }\end{array}$ & NRSC & $\begin{array}{l}2010- \\
11\end{array}$ \\
\hline $\begin{array}{l}\text { Administrative } \\
\text { Boundaries -State } \\
\text { District Village } \\
\text { and settlements }\end{array}$ & $\begin{array}{l}\text { Vector } \\
\text { Polygon }\end{array}$ & $\begin{array}{l}\text { DAC \& } \\
\text { FW -IT } \\
\text { Division }\end{array}$ & 2011 \\
\hline $\begin{array}{l}\text { Major Road } \\
\text { Vector } \\
\text { Polyline } \\
\text { layer }\end{array}$ & NRSC & $2010-$ \\
\hline Ground Truth & $\begin{array}{l}\text { Vector } \\
\text { Point layer }\end{array}$ & $\begin{array}{l}\text { CHAMAN } \\
\text { Project }\end{array}$ & $\begin{array}{l}2014- \\
15\end{array}$ \\
\hline $\begin{array}{l}\text { Cold storage } \\
\text { Infrastructure }\end{array}$ & $\begin{array}{l}\text { Tabular } \\
\text { Information }\end{array}$ & $\begin{array}{l}\text { farmer.gov. } \\
\text { in }\end{array}$ & 2015 \\
\hline $\begin{array}{l}\text { Horticulture } \\
\text { Statistics }\end{array}$ & $\begin{array}{l}\text { Tabular } \\
\text { Information }\end{array}$ & $\begin{array}{l}\text { DAC \& } \\
\text { FW }\end{array}$ & 2014 \\
\hline
\end{tabular}

Table 1. Data used and their sources 


\subsection{Methodology}

A geospatial approach was developed to evaluate the accessibility to existing cold storage infrastructure by spatially clustering horticulture land use at village level. Remote Sensing techniques were used to create potato and horticulture maps for Bihar state (MNCFC, 2015). The remote sensing outputs were then utilized for estimating proportions of horticulture land use at village level. Based on these proportions of potato and other horticulture land cover, spatial clusters were evaluated that are an indicator of horticulture significance at village level.

The distance between the villages and the existing cold storages were also computed in GIS environment. The significant horticulture region was then evaluated by clustering technique and priority villages which required cold storages were identified using following criteria:

a. Distance more than $15 \mathrm{kms}$ from existing cold storage villages.

b. Potato area more than $40 \%$ of the village area and

c. Zaid and plantation together consisting more than $60 \%$ of the village area

These identified priority villages were then assigned to the nearest settlement which accumulated the influence factor of priority villages. It is an indication of the requirement priority in a particular location. The output locations were then compared with a horticulture importance map at district level to spatially correlate horticultural important regions and cold storage distribution. The Figure 4 illustrates the flow of the study.

Remote Sensing Based Potato Crop Map and LULC Map Creation

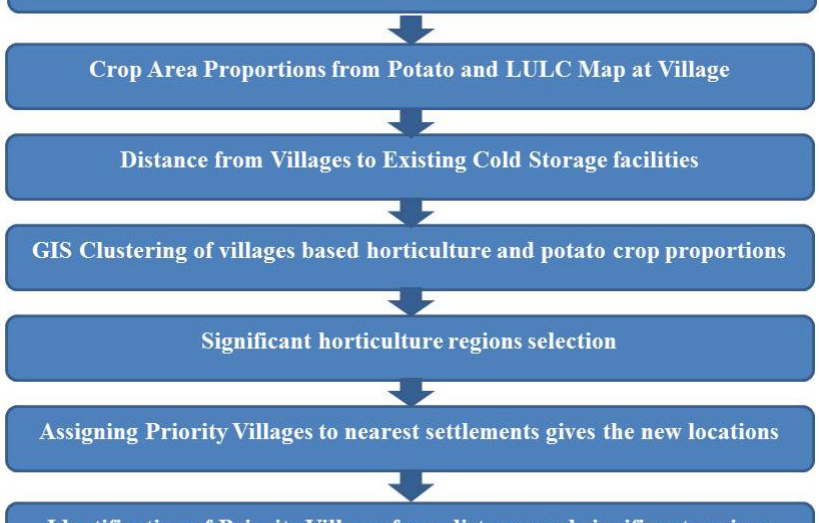

Identification of Priority Villages from distance and significant regions

Figure 4. Methodology flow chart

\section{RESULTS AND DISCUSSIONS}

\subsection{Existing Cold Storage Scenario in Bihar State}

As per the farmers portal of the government of India there are 169 cold storages in the state of Bihar (Figure 5) with a combined storage capacity of 890066 MT and an average of 5329 MT per cold storage. These cold storages are concentrated in the central districts of the state and not very well distributed in significant production regions like Patna, Nalanda and Mahbubani districts.

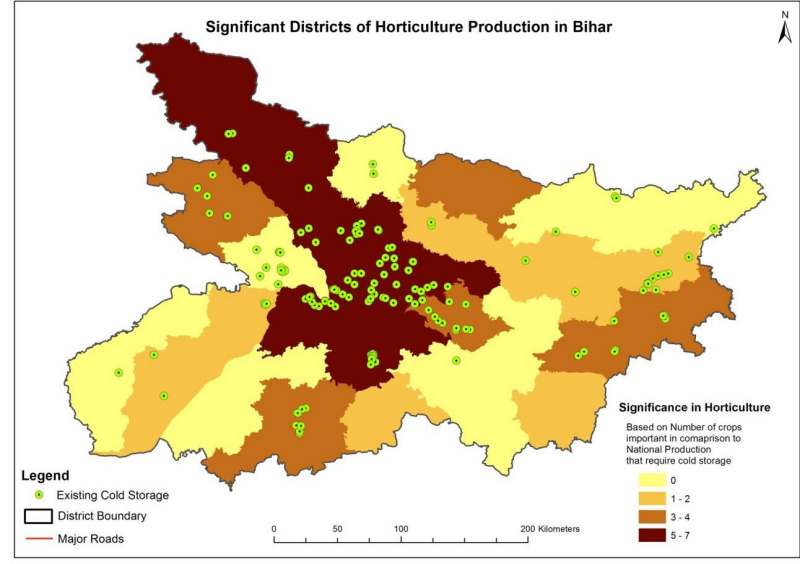

Figure 5. Significant Horticulture districts and existing cold storage distribution in Bihar

Distance map as accessibility to existing cold storage is shown in Figure 6. In some locations, the distance of travel to cold storage is very high, making it extremely difficult for the remote farmers to use the facility. This necessitated a proper planning of further cold storages.

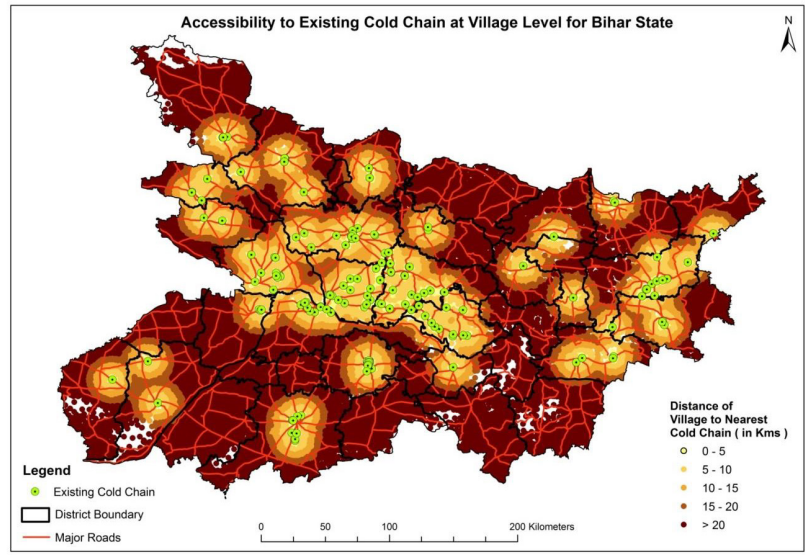

Figure 6. Distance from village to existing cold storages

Based on these proportions of potato and horticulture, land cover at village level (Figures 7 and 8), spatial clusters were evaluated that are indicators of significantly contributing regions in horticulture at village level. Figures 9 and 10 represent the output maps obtained from spatial clustering analysis and top two significance classes were combined to get the significant horticulture region which is shown in Figure 10. The significant region as shown in Figure 11 and distance analysis in Figure 6 were used to identify priority villages requiring cold storages.

Analysis of the GIS data has identified 166 priority villages (Figure 12) in 17 districts requiring cold storages which meet the selection criteria.

Villages in Madhubani, Paschim Champaran and Jehanabad districts will have average reduction in distance (of travel to cold storage) of 24.4, 18.6 and 17.5 kilometers after the new cold storages are established (Figure $13 \& 14$ and Table 2). 
The International Archives of the Photogrammetry, Remote Sensing and Spatial Information Sciences, Volume XLII-3/W6, 2019

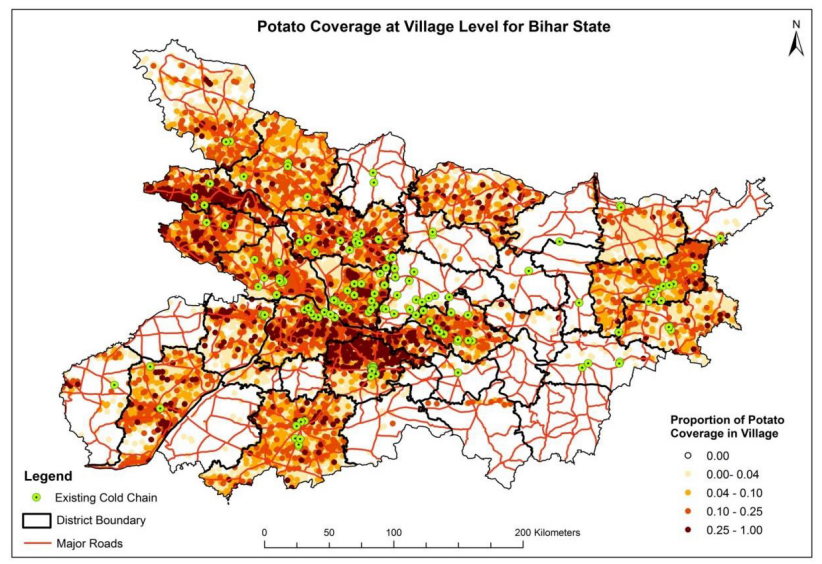

Figure 7. Potato crop area proportions for villages in Bihar. The map was created from remote sensing-based estimates.

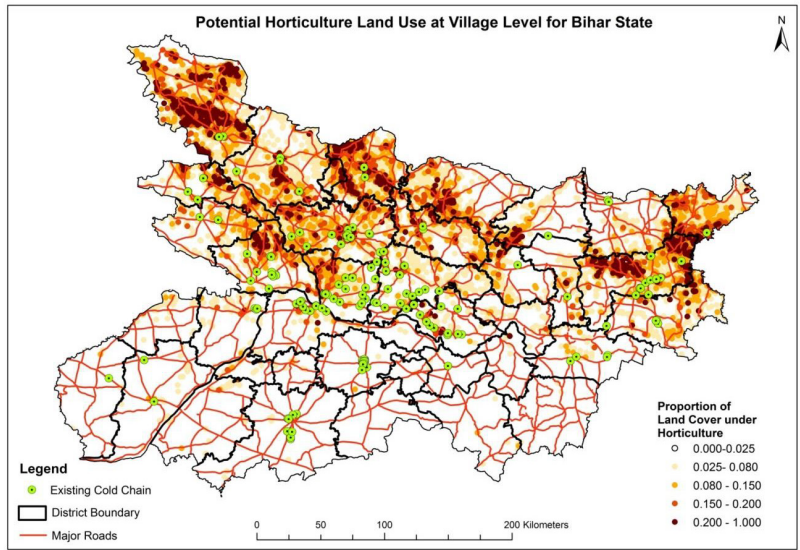

Figure 8. Horticulture land use proportions for villages in Bihar. The map was created from the LU / LC map using plantations $\&$ above crop area

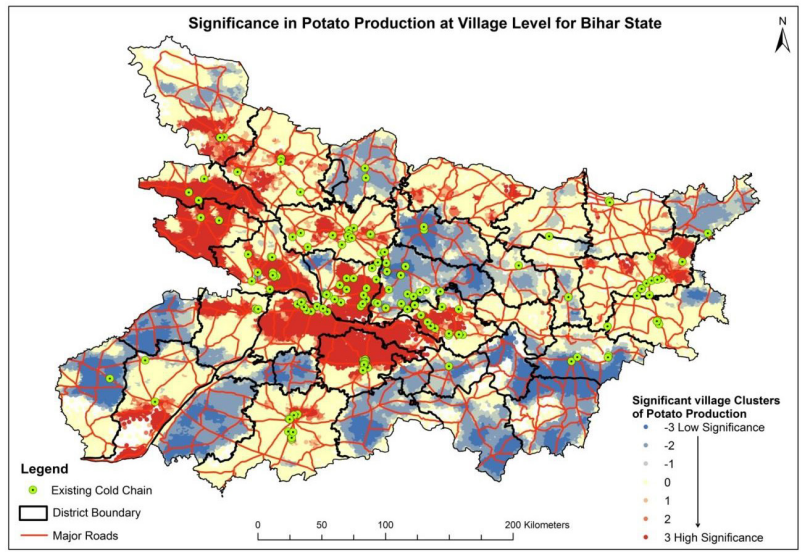

Figure 9. Significance map for the potato crop, prepared based on the potato crop proportion map

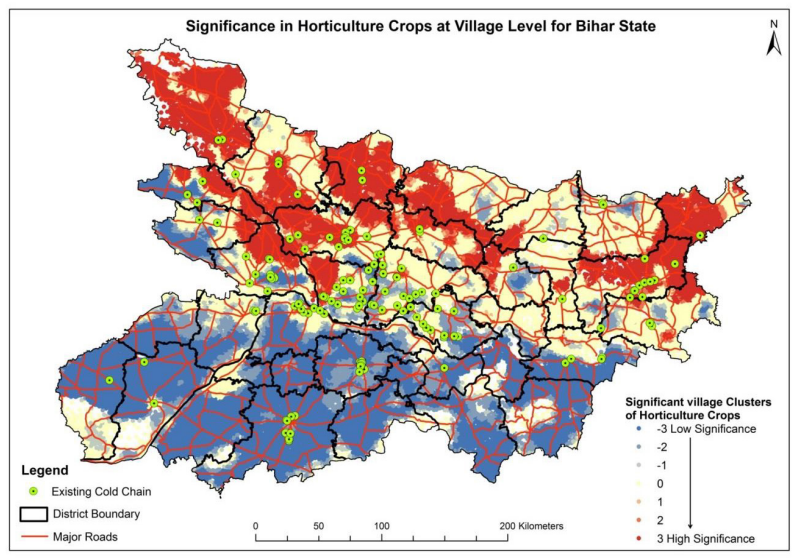

Figure 10. Significance map of horticulture crop, prepared based on the horticulture land use proportion map

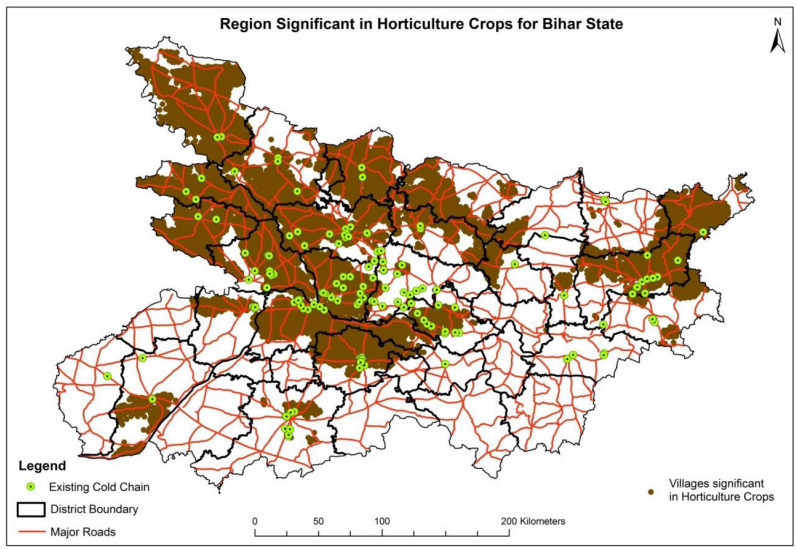

Figure 11. A significant horticulture region in Bihar obtained by union of top two classes of clustering outputs from potato and horticulture crop proportion.

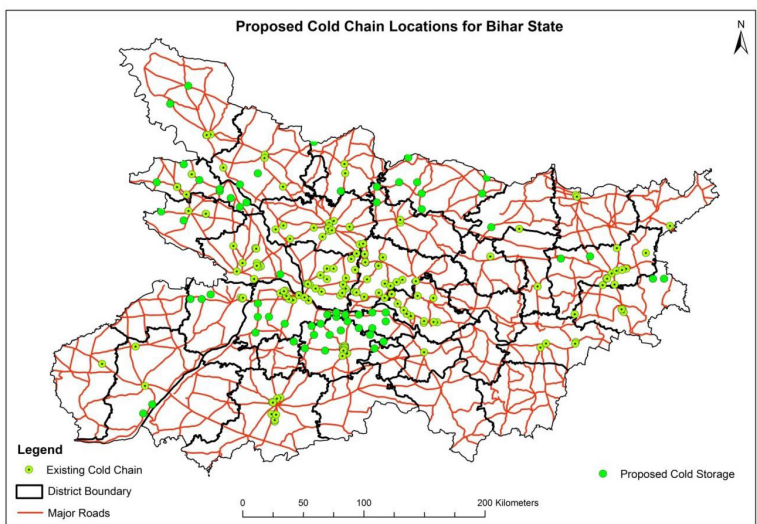

Figure 12. Map showing locations of proposed cold storages and existing cold storages in Bihar 


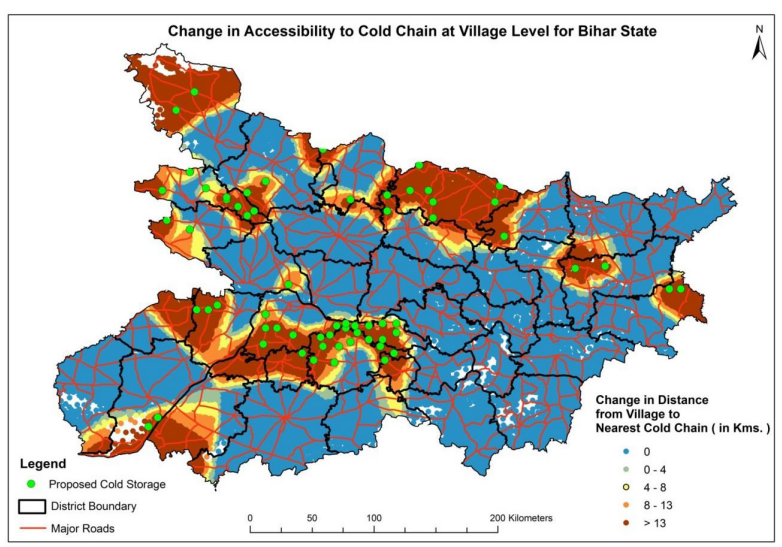

Figure 13. Map showing the reduction distance to nearest cold storage if new cold storages are established at the proposed sites

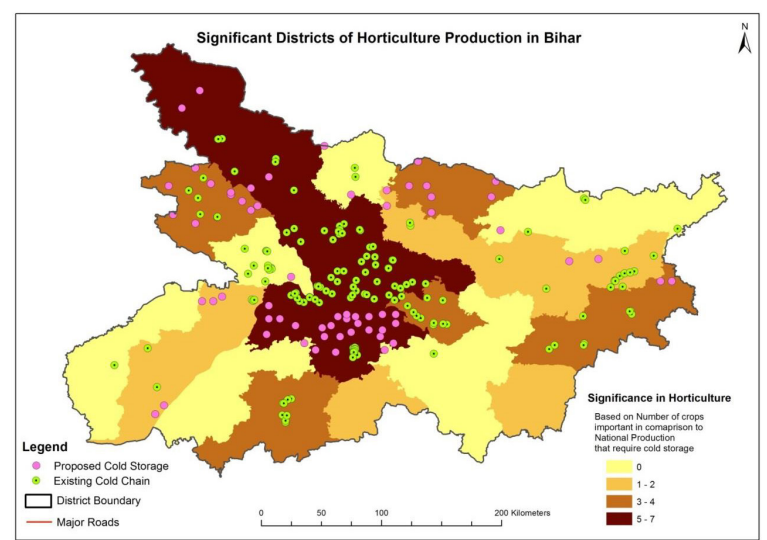

Figure 14. A visual comparison of the horticultural important districts and cold storage distribution as per the plan

\section{CONCLUSIONS}

The lack of proper cold storage infrastructure leads to post harvest losses of agriculture produce. It is very essential for a country like India, being a second highest producer of fruits and vegetables in the world, to have good post-harvest infrastructure. Government of India under the Mission for Integrated Development of Horticulture (MIDH) has initiated many schemes for the development of horticulture. Project CHAMAN is one such program which aims at using geospatial technology for the development of horticulture. In this pilot study a geospatial approach was developed to execute the postharvest infrastructure component of CHAMAN project. Bihar was an ideal choice for the pilot study as it is one of the major contributors to horticulture in the country, but has the least cold storage capacity in comparison to production.

The approach developed in this study has identified 63 locations in 17 districts for developing the new cold storage facility. The proposed new locations for cold storages will reduce the distance to the nearest cold storage for 14244 villages and this reduction in distance will be more than $8 \mathrm{kms}$ for 9774 villages. In this study the analysis is based only on distance to existing cold storages and crop area of potato and horticulture at village level. The number of cold storages was limited by adjusting the priority village criteria. The distances considered here are aerial distances, but evaluation on the basis of road network distances would be better. But for the network distances to be considered more data is required like detailed road network up to village level. Further production and consumption data at village level will add up to the efficiency of such the analysis. Siting that the available cold storage space is very less in comparison to required space the proposed cold storages will not exceed the requirement.

The study gives the settlements where cold storages have to be rather than coordinates of the location, limiting the analysis to settlement identification is better as it would be too ambitious to give high scale information siting the scale of information available for the pilot study. This pilot study has demonstrated a geospatial application for post-harvest infrastructure management and possibility of a spatial decision support system for planning in post-harvest infrastructure management.

\section{ACKNOWLEDGEMENTS}

This work was carried out under "Coordinated Horticulture Assessment \& Management Using Geoinformatics" (CHAMAN) project under Mission for Integrated Development of Horticulture (MIDH) of Ministry of Agriculture \& Farmers' Welfare, Government of India. Authors are thankful to Secretary, DAC\&FW, Additional Secretary (Horticulture), Joint Secretary (MIDH) and Adviser (Horticulture Statistics) for their constant encouragement and keen interest in the study. We area also thankful to Director and Officials of Bihar State Horticulture Department for their support for the study.

\section{REFERENCES}

Department of Agriculture and Cooperation, 2014. Hand Book on Horticulture Statistics 2014. New Delhi, India, pp.

Hegazy, R., 2013. Post-harvest Situation and Losses in India, Technical Report, June 2013, DOI: 10.6084/m9.figshare. 3206851.v1

http://farmer.gov.in/MCold_Storage_Total.aspx, Access: 15th July, 2015

http://gov.bih.nic.in/Home Page -State Profile, Acess: 28the December, 2018

MNCFC, 2015. Winter Potato Production under CHAMAN: Second (Final) Area \& Production Estimate (F2) 2014-15 using Remote Sensing Data for Bihar State, New Delhi

NCCD, 2015. All India Cold Chain Infrastructure Capacity (Assessment of Status \& Gap). Delhi

Ray S. S., Mamatha S, Manjunath KR, Uday Raj, Seshasai MVR, Singh KK, Kimothi MM, Parihar JS and Saxena, Mamta, 2016. CHAMAN: A National Level Programme for Horticultural Assessment \& Development. NNRMS Bulletin. Bangalore, India, 40: pp.1-6.

Ray, S. S., Kundu, N. Dutta, S. and Panigrahy, S., 2000. A GIS and remote sensing-based approach for siting cold storage infrastructure for horticultural crops: A case study for potato crop in Bardhaman district, West Bengal, J. Indian Soc. Remote Sensing, 28 (2\&3), pp. 171-178. 
The International Archives of the Photogrammetry, Remote Sensing and Spatial Information Sciences, Volume XLII-3/W6, 2019 ISPRS-GEOGLAM-ISRS Joint Int. Workshop on "Earth Observations for Agricultural Monitoring”, 18-20 February 2019, New Delhi, India

\begin{tabular}{|c|c|c|c|c|c|c|c|}
\hline District & $\begin{array}{c}\text { No. of } \\
\text { Villages } \\
\text { in District }\end{array}$ & $\begin{array}{l}\text { Exist } \\
\text { ing } \\
\text { Cold } \\
\text { Stora } \\
\text { ges }\end{array}$ & $\begin{array}{c}\text { New } \\
\text { Cold } \\
\text { Stora } \\
\text { ges }\end{array}$ & $\begin{array}{l}\text { Beneficia } \\
\text { ry } \\
\text { Villages } \\
\text { Change } \\
>8 \mathrm{kms}\end{array}$ & $\begin{array}{l}\text { Average } \\
\text { Change in } \\
\text { Distance } \\
(\mathrm{km})\end{array}$ & $\begin{array}{c}\text { Priority } \\
\text { Villages } \\
\text { assigned to } \\
\text { new CS }\end{array}$ & New Locations \\
\hline Araria & 776 & 2 & - & 87 & 2.2 & & - \\
\hline Arwal & 371 & - & - & 330 & 16.5 & & - \\
\hline Aurangabad & 1819 & - & 1 & 862 & 7.9 & 1 & Tilothu \\
\hline Banka & 1650 & - & - & - & - & & - \\
\hline Begusarai & 999 & 13 & - & - & - & & - \\
\hline Bhagalpur & 1472 & 4 & - & - & - & & - \\
\hline Bhojpur & 1078 & 3 & 3 & 604 & 10.5 & 12 & Rani Sagar, Shahpur, Benwaliya \\
\hline Buxar & 1064 & - & - & 415 & 9.4 & & - \\
\hline Darbhanga & 1346 & 2 & 2 & 216 & 2.9 & 2 & Barhampura, Jogiara \\
\hline Gaya & 2820 & 8 & - & 87 & 0.6 & & -- \\
\hline Gopalganj & 1511 & 4 & 5 & 676 & 7.6 & 22 & $\begin{array}{l}\text { RatanSarai, Barauli, Bhore, Harkhua, } \\
\text { KuchaiKot }\end{array}$ \\
\hline Jamui & 1473 & - & - & - & - & & - \\
\hline Jehanabad & 575 & - & 1 & 435 & 17.5 & 2 & Phalgu River \\
\hline $\begin{array}{l}\text { Kaimur } \\
\text { (bhabua) }\end{array}$ & 1689 & 1 & & 47 & 0.4 & & - \\
\hline Katihar & 1555 & 3 & 2 & 626 & 7.9 & 3 & Benibari, Sudhani \\
\hline Khagaria & 313 & - & - & - & 0.0 & & - \\
\hline Kishanganj & 825 & 1 & - & - & 0.0 & & - \\
\hline Lakhisarai & 475 & 1 & - & - & 0.0 & & - \\
\hline Madhepura & 456 & 2 & - & 35 & 1.4 & & - \\
\hline Madhubani & 1175 & - & 7 & 1128 & 24.4 & 11 & $\begin{array}{l}\text { Pandaul, Madhubani, Narahia, Benipatti, } \\
\text { Koluahi, Laukahi, Harlakhi }\end{array}$ \\
\hline Munger & 791 & - & 1 & -- & 0.0 & 3 & Bar Bigha \\
\hline Muzaffarpur & 2020 & 14 & & 85 & 0.8 & & - \\
\hline Nalanda & 1037 & 12 & 8 & 566 & 9.7 & 41 & $\begin{array}{l}\text { Parwalpur, Ram Bhawan, Sarmera, Hilsa, } \\
\text { Chandi, PaimarNadi, Diawan, Nagar Nahusa }\end{array}$ \\
\hline Nawada & 1086 & - & - & 8 & 0.6 & & - \\
\hline $\begin{array}{l}\text { Pashchim } \\
\text { Champaran }\end{array}$ & 1504 & 4 & 2 & 939 & 18.6 & 2 & Patilar, Mujra \\
\hline Patna & 1467 & 13 & 17 & 873 & 10.8 & 34 & $\begin{array}{l}\text { Bind, Barathpura, Gonawan, Saksohra, } \\
\text { Nadwan, MohanaNadi, Sarhan, Bikram, } \\
\text { Jaitipur, NonaiNadi, Khusropur, } \\
\text { Bakhtiyarpur, Athmalgola, Karowta, Barh, } \\
\text { Punarakh, Bihta }\end{array}$ \\
\hline $\begin{array}{l}\text { PurbaChampa } \\
\text { ran }\end{array}$ & 1325 & 8 & 2 & 208 & 2.6 & 3 & Bhawanipur, Kotwa \\
\hline Purnia & 1339 & 12 & 2 & 213 & 3.2 & 3 & Jankinagar, Champanagar \\
\hline Rohtas & 2016 & 2 & 1 & 131 & 1.3 & 1 & Tumba \\
\hline Saharsa & 472 & 1 & 1 & 2 & 0.2 & 1 & Supaul \\
\hline Samastipur & 1473 & 20 & & 1 & 0.1 & & - \\
\hline $\begin{array}{l}\begin{array}{l}\text { Saran } \\
\text { (chhapra) }\end{array} \\
\end{array}$ & 1762 & 13 & 4 & 100 & 1.1 & 5 & $\begin{array}{l}\text { Sitalpur, DighwaDubawli, Baikunthpur, } \\
\text { Sidhwalia }\end{array}$ \\
\hline Sheikhpura & 307 & - & - & 199 & 11.0 & & - \\
\hline Sheohar & 125 & - & -- & 4 & 1.0 & & - \\
\hline Sitamarhi & 927 & 2 & 2 & 224 & 4.2 & 2 & Runni, Bairagnia \\
\hline Siwan & 1481 & 3 & - & 445 & 5.3 & & - \\
\hline Supaul & 578 & - & - & 172 & 5.3 & & - \\
\hline Vaishali & 1582 & 21 & - & 1 & 0.1 & & - \\
\hline
\end{tabular}

Table 1: Details of suitable sites for positing new cold storage facility and analysis 